\title{
ANALYSIS OF SATISFACTION FROM AGROTOURISM VISITORS AT THE STRAWBERRY GARDENS OF MAGELANG REGENCY
}

\author{
Yanuarius Ongki Saputra ${ }^{1^{*}}$, Bayu Nuswantara ${ }^{1)}$ \\ ${ }^{1}$ Satya Wacana Christian University \\ ${ }^{*}$ Corresponding author: 522016098@student.uksw.edu
}

To cite this article:

Saputra, Y., \& Nuswantara, B. (2021). Analysis of Satisfaction from Agrotourism Visitors at the Strawberry Gardens of Magelang Regency. JIA (Jurnal IImiah Agribisnis) : Jurnal Agribisnis dan IImu Sosial Ekonomi Pertanian, 6(5), 164 - 176. doi:http://dx.doi.org/10.37149/jia.v6i5.20650

Received: September 15, 2021; Accepted: September 27, 2021; Published: September 29, 2021

\begin{abstract}
In this day of increasing tourist visitations, it is necessary to maintain the quality of sightseeing so that final Satisfaction will continue to rise or at least not drop in the mutual Satisfaction of visiting strawberry Britain Diagro. Therefore, to maintain an object quality in the ministry, it is necessary to meet the customer's needs and thus achieve customer satisfaction. Using the method for importanceperformance analysis (science) can assess any quality needed for improvement. Using the customer index (CSI) method may be known to the customer's overall satisfaction level. The study was carried out from January to May 2021 for about 30 days. As for the research facility carried out at strawberry banyuroto, with the address of the village of banyuroto, the mageagle sawmill. Street. The captain of the ketep passed $1.3 \mathrm{~km}$. There are five variables used in this study: price, product, promotion, and place. The study USES an impressive. Sampling with the number of respondents taken in this study as many as 50. A calculation by a customer satisfaction index (CSI), the score of CSI at $81,02 \%$. Such a value suggests that customers are satisfied with services rendered while using an imperativeperformance analysis method. It is known that attributes need to be made for performance improvements to improve the decision.
\end{abstract}

Keywords: agrotourism; high strawberry; visitor satisfaction

\section{INTRODUCTION}

Agritourism is a tourist attraction using agricultural enterprises as a tourist attraction. The aim is to expand knowledge, leisure experiences, and agricultural partnerships by developing local cultures tapping on land. Farmers' income can increase, and efforts to conserve land resources and maintain local cultures and technology that are generally informed of their natural environment. The growing agrotourism offers fresh agricultural products to make a customer's consumption and can be enjoyed by the consumer by direct purchase from the farmer(Popescu, 2015).

According to Hermawan (2015), a marketing mix will increase consumer decisions, Satisfaction, and loyalty in purchasing. Later, it will have an impact on improving the quality of the company's competitiveness. According to Mawahib (2015), the product marketing mix will enhance the structure of purchasing decisions to increase the achievement of company targets. According to Sulaiman (2015) with the marketing mix, it will increase consumer confidence in the quality of the brands offered by the company to impact the excellent image of the company by consumers. According to Assauri (2013), a Marketing mix is a combination of variables or activities that Is at the heart of the marketing system, which variables can be controlled by marketing to affect the reactions of customers or consumers. According to Alma (2016), "Marketing Mix" mix marketing activities to find the maximum combination to bring the most satisfying results.

According toTjiptono (2012), producers offer a product for attention, interest, purchase, and consumption to fulfil the needs and desires of the relevant market. In comparison, the product Malau (2017) is an actual item that is visible or tangible and even handheld designed to satisfy consumer wants or needs such as computers, cars, scrubs, teeth, food, etc. According to Suparyanto \& Rosad (2015), price is the amount of something that has value generally in the form of money that must be 
sacrificed to get a product. Based on this description, it can be concluded that place is the only element that can generate income, which will impact the size of the profit and the size of the market share obtained. According to Umar (2013), communicating the product In the community requires developing a promotion mix consisting of four components: the main are advertising and sales promotion. According to Hurriyati (2015), the place is one of the activities that every producer needs to do is move or distribute products, goods, or services produced from one place to another.

Inggit Strawberry Agrotourism is a plantation-based tourism area located close to the KetepPass Sawangan Magelang tourist attraction. The first land area is five thousand square meters, and the second land is two thousand square meters. The main attraction offered by Inggit Strawberry Agrotourism is the tour of picking Strawberry fruit straight from the garden. The existence of this agrotourism is quite attractive to tourists, especially family tourists. The Inggit Strawberry Agrotourism area has dozens of Strawberry orchards belonging to residents, but not all are cultivated for fruit picking tours. Some Strawberry orchards are pretty narrow and only as a distraction. In addition to the beautiful location and attractions in Inggit Strawberry Agrotourism, the increase in visitors is also due to the interest in visiting again after seeing and visiting these attractions. Several things that also influence the interest in revisiting Inggit Strawberry Agrotourism are the marketing mix provided by the manager, including price, product, promotion, and location. The manager applies an attractive price policy for agro-tourism visitors who come to the place. The price offered by the manager, in the form of an entrance ticket of Rp.five thousand,-per person and the cost of fruit picking per ounce is ten thousand. This price is quite affordable and following the facilities provided, even more, competitive than other agrotourism.

The tourist visits in this agrotourism will usually increase on weekends and holidays until it reaches three times that of normal days or about 50-70 visitors per day. Visitors typically enjoy the tour packages provided by the manager in picking strawberries, places for photos and selfies, shopping for regional souvenirs, and enjoying panoramic views of the mountains and strawberry orchards. As one of the tourism objects in the Magelang Regency, which is at the foot of Mount Merbabu and close to Mount Merapi, Agrotourism Inggit Strawberry also faces competition with other agrotourism located in the area of Mount Merbabu and Mount Merapi. To maintain the existence and sustainability of this agro-tourism, it is necessary to support an increase in tourist visits by preserving the quality of tourism objects so that visitor satisfaction continues to increase or at least does not decrease in terms of visitor satisfaction at Strawberry Inggit. Based on the background, can be formulated research problem: What is the level of Satisfaction of visitors agro-based on attributes of the marketing mix in the garden Inggit Strawberry? And which characteristics of the marketing mix need attention from the garden manager? From the background and problems above, the research objectives

According to Dany (2018), To find out the customer satisfaction index for the services that Markobar has provided and to find out the attributes per dimension that need to be improved by Markobar to improve the quality of their services, it can be concluded. The results obtained from calculations using the Customer Satisfaction method Index (CSI) obtained a satisfaction index of $76.36 \%$. This value is included in the "satisfied" category. This shows that customers are satisfied with the services provided by Markobar. However, by looking at these results, there are still attributes that need to be improved so that future improvements can increase customer satisfaction. A negative gap value indicates that Satisfaction is less than the value of importance, then the service is said to be of poor quality and unsatisfactory.

According to Simanullang, (2018) To determine the level of tourist satisfaction with the services provided by the Pondok Permai Beach, Serdang Bedagai Regency, North Sumatra in improving the quality of its services and To find out how service attributes are based on the level of importance and level of performance according to tourists at Pondok Permai Beach, Serdang Bedagai Regency, North Sumatra, the conclusion of the Customer Satisfaction Index, it can be seen that the CSI value of 667.654 is rounded up to 0.66 , the value is in the $0.66-0.80$ interval where The value is in the interval $0.66-0.80$ tourists feel "satisfied" with service performance on service quality at Pondok Permai Beach, Serdang Bedagai Regency, North Sumatra and Seven attributes that are considered essential and determine service quality at Pondok Permai Beach include (attributes 10) cleanliness and tidiness in Pondok Permai Beach environment, (attribute 11) supporting facilities and environment such as the availability of parking lots, toilets, and trash cans, (attribute 13) suitability of ticket prices with existing facilities at Pondok Permai Beach, (attribute 14) comfort and safety while at Pondok Permai Beach, (attribute 18) the dedication and patience of employees in providing services, (attribute 19) place/means for submitting complaints, criticisms or suggestions, (attribute 20) image or image of Pondok Permai Beach in the eyes of tourists to its visitors. It is shown in quadrant I in the Cartesian diagram. 
According to Diana (2014), they know the level of importance of each attribute based on the method Importance Performance Analysis (IPA) and understanding the level of customer satisfaction based on the Customer Satisfaction Index (CSI) method. Conclusions from the Customer Satisfaction Index (CSI) are used to determine the overall level of customer satisfaction and obtained a CC value of $66,51 \%$. Thus it can be concluded that overall, consumers are satisfied with the restaurant attributes of Ria Djenaka Coffee \& Resto.

According to Risep (2018), to determine the level of customer satisfaction of OIS Photography with the service and company performance felt and select the criteria that become service prioritiesusing the Customer Satisfaction Index (CSI) method to determine the level of consumer satisfaction and the Importance Performance Analysis (IPA) method to identify the level of importance of each service attribute and improvement priorities that OIS Photography must carry out. Between 21 and 30 years old, consumers with the last educational level of Bachelor (S1, S2, S3) are the dominant consumers. The story of consumer satisfaction with OIS Photography based on CSI is $74.19 \%$. Based on the IPA method, there are 3 (three) attributes in quadrant A: attributes of improvement, namely the variety of various photography service options, the short waiting period for photo prints, the ability of employees to understand consumer desires.

According to Saula (2019), good attribute management effectively attracts consumer interest and can be improved by measuring tourist satisfaction. North Sumatra is one of the provinces that are most often a tourist destination. One of the tourist areas in North Tapanuli has excellent potential to become mainstay tourism, and bathing tourism is considered the most potential. Three baths are considered the most popular: Sipoholon Hot Springs, Soda Water Baths, and Tamaro Hot Springs. Based on this, it is necessary to improve the tourism attributes, including attractions, amenities, accessibility, and tourist satisfaction, to obtain priority improvements to the specified indicators that impact tourism efficiency. The method used in this research is the Customer Satisfaction Index Method and Importance Performance Analysis. The study results obtained that the CSI value was $68.89 \%$, included in the satisfied category. Through the IPA method, it was found that there were still eight tourism attributes that needed priority improvement.

According to Haris (2020), Customer Satisfaction Using Service Quality, Importance Performance Analysis and Customer Satisfaction Index Methods] Data collection was carried out using a questionnaire, data processing was carried out using the Servqual method, Importance Performance Analysis (IPA), and Customer Satisfaction Index (CSI). The study results indicate that customers are delighted with the services provided but have not been maximized. This can be seen from testing the customer satisfaction index using the Customer Satisfaction Index (CSI) method, 91\%. In testing using the Importance Performance Analysis (IPA) method, five attributes are included in Quadrant I, which means five service attributes are not maximized. Based on the Servqual method testing, the improvement order starts from attribute E1 (laundry can resolve customer complaints), which has the most significant negative value.

Based on the three journals, there are differences, namely from location and variables. It can be concluded that this research has been updated in areas and variables to continue this research.1) Analyzing the agrotourism visitor satisfaction index on the attributes of the agrotourism marketing mix in inggit strawberry gardens 2). Analyzing the attributes of the agrotourism marketing mix that need to be considered by the Inggit Strawberry garden

\section{MATERIALS AND METHODS}

This research was conducted from January to May 2021 for approximately 30 days. The study was conducted in Agrotourism Inggit Strawberry Banyuroto, with Banyuroto Village, Sawangan District, Magelang. Jl. Kaponan Ketep Pass $1.3 \mathrm{~km}$. According to Evi (2018), descriptive is research for describing the symptoms phenomena or facts studied by explaining the variable's value independently, without intending to connect or compare. This quantitative descriptive research uses one variable in its operation, but it can also use two or more variables or look for cause and effect between variables. This study attempts to describe variables based on indicators and descriptors of research variables. The data collection technique used in this study is as follows: Sampling in this study was conducted by method non-probability sampling characterized by not being given the same opportunity for each member of the population to be selected as a sample. The non-probability selection chosen was using method purposive sampling, namely the sampling technique based on particular or needs that are considered to have a close relationship with aspects purposive indicate that this sampling technique is used to achieve specific goals related to the sample (respondent) that will be taken to represent the population in this study. Several subjective considerations are appropriate or relevant to the research objectives, which in this sampling are based on age (above 17 
years), and have visited Inggit Strawberry Agrotourism. The selection was carried out on tourist visitors who visited the Inggit Strawberry Agrotourism 50 respondents.

Table 1. Definition and measurement of variables

\begin{tabular}{|c|c|c|c|}
\hline Variable & Definition Variable & Attribute & Measurement \\
\hline Price $\left(\mathrm{X}_{1}\right)$ & $\begin{array}{l}\text { Price is the amount of something } \\
\text { that has value generally in the } \\
\text { form of money that must be } \\
\text { sacrificed to get a product. } \\
\text { (Suparyanto \& Rosad, 2015) }\end{array}$ & $\begin{array}{l}\text { 1. price with quality } \\
\text { 2. price compared to } \\
\text { competitors } \\
\text { 3. price according to benefits } \\
\text { 4. price list }\end{array}$ & $\begin{array}{l}\text { Likert scale } \\
\quad(1-5)\end{array}$ \\
\hline Product $\left(\mathrm{X}_{2}\right)$ & $\begin{array}{l}\text { Product is offered by producers } \\
\text { for attention, interest, purchase, } \\
\text { and consumption by the market to } \\
\text { fulfil the needs and desires of the } \\
\text { relevant market. (Tjiptono, 2012) }\end{array}$ & $\begin{array}{l}\text { 1. fruit packaging shape } \\
\text { 2. strawberry quality } \\
\text { 3. fruit size } \\
\text { 4. product guarantee }\end{array}$ & $\begin{array}{l}\text { Likert scale } \\
\quad(1-5)\end{array}$ \\
\hline $\begin{array}{l}\text { Advertising } \\
\text { Promotion } \\
\left(X_{3}\right)\end{array}$ & $\begin{array}{l}\text { Advertising is any paid non- } \\
\text { personal presentation and } \\
\text { promotion of an identified } \\
\text { sponsor's ideas, goods, or } \\
\text { services. (Shinta, 2017) }\end{array}$ & $\begin{array}{l}\text { 1. banners } \\
\text { 2. brochures } \\
\text { 3. Facebook } \\
\text { 4. Instagram }\end{array}$ & $\begin{array}{l}\text { Likert scale } \\
\quad(1-5)\end{array}$ \\
\hline $\begin{array}{l}\text { Sales } \\
\text { promotion } \\
\left(X_{3}\right)\end{array}$ & $\begin{array}{l}\text { Sales promotion is the core } \\
\text { ingredient in a marketing } \\
\text { campaign, consisting of a } \\
\text { collection of incentive tools, } \\
\text { mostly short-term, designed to } \\
\text { stimulate the quicker or more } \\
\text { excellent purchase of a particular } \\
\text { product or service by consumers } \\
\text { or traders. (Shinta, 2017) }\end{array}$ & $\begin{array}{l}\text { 1. special discount } \\
\text { 2. product sample giving } \\
\text { (strawberry) } \\
\text { 3. free product packing } \\
\text { (strawberry) }\end{array}$ & $\begin{array}{l}\text { Likert scale } \\
\quad(1-5)\end{array}$ \\
\hline Location $\left(\mathrm{X}_{4}\right)$ & $\begin{array}{l}\text { One of the activities that every } \\
\text { producer needs to do is move or } \\
\text { distribute products, goods, or } \\
\text { services produced from one place } \\
\text { to another. (Hurriyati, 2015) }\end{array}$ & $\begin{array}{l}\text { 1. strategic location } \\
\text { 2. layout }\end{array}$ & $\begin{array}{l}\text { Likert scale } \\
\quad(1-5)\end{array}$ \\
\hline
\end{tabular}

\section{Customer Satisfaction Index}

According to Suryawan (2013), customer satisfaction (Customer Satisfaction) is determined by the perception of customers on performance (performance) product or service in meeting expectations customer. Customers will be satisfied if the expectations are fulfilled or very satisfied if the expectations are exceeded. The level of customer satisfaction can be measured by a method called the Customer Satisfaction Index (CSI). This analysis is used to answer the number one goal, which is to measure the overall level of visitor satisfaction in Inggit Strawberry agro-tourism.

This CSI Measurement Method includes the following steps:

1. Calculating the Weighting Factor (WF)

Weighting Factor changes the average value of the importance level to a number percentage of the total intermediate level of importance to a number percentage of the full average level of importance of all variables involved tested obtained.

Weighting Factors $100 \% \mathrm{wf}=\frac{R s p}{\Sigma R s p} \times 100 \%$

Description: $\mathrm{WF}=$ weighting factors $(\%), \mathrm{Rsp}=$ average score of interest

2. Calculating the Weighted Score (WS)

Weighted Score multiplication value between the average levels of performance/satisfaction respectively-each variable with weighting factors (WF) for each variable

Ws $=$ RSK $\times$ WF

Description :WF=weighting factors(\%), RSK=average performance score

3. Calculating Weighted Median Total (WMT)

Weighted Median Total is adding up the weighting scores of all variable service quality. $\mathrm{Wt}=\mathrm{WS} 1+\mathrm{WS} 2+\mathrm{WS} 3+\ldots \mathrm{WSn}$

Description: WS1=weighting factors to $1, W S n=$ weighting factors to $n$ 
4. Calculating satisfaction index (SI), i.e., Weighting Total (WT) divided by the maximum scale used then multiplied by $100 \%$

$$
\mathrm{CSI}=\frac{w t}{\text { maximum score }} \times 100 \%
$$

Table 2. Customer Satisfaction Index (CSI) interpretation

\begin{tabular}{cc}
\hline CSI Value $(\%)$ & Interpretation \\
\hline $0<\mathrm{CSI} \leq 20$ & Very dissatisfied \\
$20<\mathrm{CSI} \leq 40$ & Not satisfied \\
$40<\mathrm{CSI} \leq 60$ & Quite satisfied \\
$60<\mathrm{CSI} \leq 80$ & Satisfied \\
$80<\mathrm{CSI} \leq 100$ & Very satisfied \\
\hline
\end{tabular}

Sumber: Customer Satisfaction Index (Santoso, 2018)

\section{Importance Performance Analysis}

According to Vivi (2017), Importance Performance Analysis is a technique to measure the attributes of the level of (importance) and the level of implementation/performance (performance) helpful in developing an effective marketing program. This method is used to analyze the expectations and execution of consumer satisfaction. This analysis is used to measure the attributes that need improvement in Inggit Strawberry agro-tourism to answer the number two objective, namely the study of agro-tourism marketing mix attributes that need to be considered by the Inggit Strawberry garden.

Then the results of the data obtained are processed by Importance Analysis Matrix. Importance Analysis Matrix is a matrix that explains the comparison between the level of expectations and the level of performance through the division based on the quadrant of each of these attributes, where the $x$-axis is the axis that represents consumer perceptions of execution. In contrast, the $y$ axis represents consumer expectations. First, calculate the average value of consumer perceptions of the level of expectation and the level of performance of each attribute with the following equation formula.

$$
X=\frac{X 1 \Sigma}{n} \mathrm{n} ; Y=\frac{Y 1 \Sigma}{n}
$$

Description: $X=$ Average - Average score level performance, $Y=$ Average - Average score level expectations, $n=$ number of samples used

Second, calculate the average score of the level of expectation and performance of each attribute. The average value is used as the limit in the Cartesian diagram. The following equation is used in determining the boundaries of the Cartesian graph.

$$
\bar{X}=\frac{\Sigma X \overline{\bar{I}}}{k} \mathrm{k} ; \overline{\bar{Y}}=\frac{\Sigma Y \overline{\bar{Y}}}{k}
$$

Description: $\overline{\bar{X}}=$ Average - Average score level of performance all the attributes, $\overline{\bar{Y}}=$ Average Average score level Hope all the attributes, $k=$ number of features used

The last stage, the translation of the results of each attribute in the Cartesian diagram. The following is a Cartesian picture with four quadrants

\begin{tabular}{c|c|c|}
\multicolumn{1}{c|}{} & \multicolumn{2}{c|}{ Cartesian diagram } \\
\cline { 2 - 3 } Interest & $\begin{array}{c}\text { Quadrant I } \\
\text { Main priority }\end{array}$ & $\begin{array}{l}\text { Quadrant II } \\
\text { Maintained }\end{array}$ \\
\cline { 2 - 3 } $\mathbf{Y}$ & $\begin{array}{c}\text { Quadrant III } \\
\text { Low priority }\end{array}$ & $\begin{array}{c}\text { Quadrant IV } \\
\text { Excessive }\end{array}$ \\
\cline { 2 - 2 } & \multicolumn{2}{|c|}{ X performance }
\end{tabular}

Figure 1. Cartesian diagram of performance level and importance different conditions.

Each attribute has a different strategy based on the position of the feature, which is as follows:(Yudi, 2017)

1. Quadrant I (Main priority) In this quadrant, consumers consider some factors essential and or expected, but the company's performance is deemed unsatisfactory. Hence, the company needs to concentrate on allocating its resources to improve its performance in this quadrant.

2. Quadrant II (Maintained) In this quadrant, factors are considered essential and are expected to support customer satisfaction so that companies are obliged to maintain performance achievements. 
3. Quadrant III (Low Priority)In this quadrant, factors are considered to have a low level of perception or actual performance and are not too essential and or not too expected by consumers. Companies do not need to prioritize or prioritize pay more attention to these factors.

4. Quadrant IV (Excessive ) Some elements are considered unimportant and not too expected by customers in this quadrant. The company is better at allocating these factors to other factors with a higher priority level.

\section{RESULTS AND DISCUSSION}

\section{Characteristics of Respondents}

Consumer characteristics are a picture of consumer identity. Each consumer has a different age, gender, occupation, education, and income characteristics to meet their daily needs (Santi, 2012). Characteristics of Respondents explain the Satisfaction of tourist visitors in Inggit Strawberry Agrotourism in Magelang Regency, which is needed as information material to determine tourist visitor satisfaction given by the manager of Inggit Strawberry Agrotourism in this study with a total of 50 visitors as respondents. Then the presentation of data regarding the characteristics or identity of the respondent is carried out, namely to find out a picture of the respondent's self. The characteristics of the respondents in this study include gender, age, education level, occupation, address, level of visits, reasons for visiting, and monthly income.

Table 3. Characteristics respondents

\begin{tabular}{|c|c|c|}
\hline Characteristics & Number of Respondents & Presentation \\
\hline \multicolumn{3}{|c|}{ 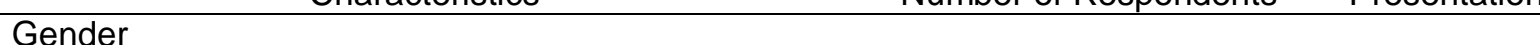 } \\
\hline Male & 21 & 42 \\
\hline Female & 29 & 58 \\
\hline \multicolumn{3}{|l|}{ Age } \\
\hline $17-25$ & 28 & 56 \\
\hline $26-35$ & 19 & 38 \\
\hline $36-45$ & 2 & 4 \\
\hline $46-55$ & 1 & 2 \\
\hline \multicolumn{3}{|l|}{ Education } \\
\hline Grade school & 0 & 0 \\
\hline high school first & 1 & 2 \\
\hline High school & 13 & 26 \\
\hline certication & 7 & 14 \\
\hline Scholar 1 & 27 & 54 \\
\hline Scholer $2 / 3$ & 2 & 4 \\
\hline \multicolumn{3}{|l|}{ Occupation } \\
\hline Civil servants/state & 3 & 6 \\
\hline Owned enterprises private employees & 22 & 44 \\
\hline Self-employed & 7 & 14 \\
\hline Indonesia national guard/police & 0 & 0 \\
\hline Student & 12 & 24 \\
\hline Entrepreneur & 3 & 6 \\
\hline Others & 3 & 6 \\
\hline \multicolumn{3}{|l|}{ Respondent's Address } \\
\hline Banyubiru & 1 & 2 \\
\hline Boyolali & 3 & 6 \\
\hline Bandungan & 1 & 2 \\
\hline Bawen & 2 & 4 \\
\hline Grobogan & 1 & 2 \\
\hline Central Kalimantan & 1 & 2 \\
\hline Kendal & 1 & 2 \\
\hline Lampung & 3 & 6 \\
\hline Magelang & 13 & 26 \\
\hline Pati & 1 & 2 \\
\hline Purwodadi & 1 & 2 \\
\hline Salatiga & 4 & 8 \\
\hline Semarang & 3 & 6 \\
\hline
\end{tabular}


Table 3. Characteristics respondents

\begin{tabular}{lcc}
\multicolumn{1}{c}{ Characteristics } & Number of Respondents & Presentation \\
\hline South Sumatra & 1 & 2 \\
Solo & 1 & 2 \\
Ungaran & 3 & 6 \\
Yogyakarta & 10 & 20 \\
\hline Number of visits & 37 & 74 \\
First & 9 & 18 \\
$2-3$ times & 3 & 6 \\
3-4 times & 1 & 2 \\
$>5$ times & & \\
\hline Reasons & 10 & 20 \\
Affordable ticket prices & 19 & 38 \\
Strategic locations & 21 & 42 \\
Security and comfort atmosphere & 0 & 0 \\
School assignments /office assignment & & \\
\hline Income Monthly Income & 17 & 34 \\
$<2.5$ million & 20 & 40 \\
2.5-5 million & 7 & 14 \\
5 million & 6 & 12 \\
$>5$ million & &
\end{tabular}

Source: Processed Primary Data, 2021

Based on the data on gender characteristics in Table 3. above, it can be seen below, most of the visitors who travel to Agrotourism Inggit Strawberry are 29 female visitors with a presentation of $58 \%$, while 21 female visitors also with a percentage of $42 \%$. Thus the majority of these visitors are female, as much as $58 \%$. Because the respondents who were met at the location of Inggit Strawberry Agrotourism mainly were with their partners, friends, and family. According to Saula (2019), Based on the data from the research that has been done, the respondents in Agrotourism Inggit Strawthe results of the study, of all tourists who became respondents, $55 \%$ of visitors were women, the remaining $45 \%$ were men. which was obtained from 50 respondents by being carried out for more than one month, it was seen that the number of men was less than that of women. It could be said that the highest number of visitors was women. Berry, based on age, has a reasonably high diversity. The age distribution data of respondents.

According to Saula (2019), research results obtained that tourists with the most significant proportion are $17-25$ years by $47 \%, 26-35$ years by $22 \%, 36-45$ years $15 \%, 46-55$ years $10 \%$, and over 55 years $6 \%$. It can be concluded that the younger age then the possibility of tourism is increasing. The table above shows that most of the respondents who visited Inggit Strawberry Agrotourism were 17-25 years old, as many as 28 people or $56 \%$, while the lowest respondents were respondents aged between $46-55$ years, namely one person or $2 \%$. This shows that the respondents who visited the Inggit Strawberry agro-tourism were of working age and entered at the age of students. Getting younger generation then the possibility to do tourism is increasing.

According to Pasdo (2018), Low level of education (no school - elementary school), moderate level of education (SMP-SMA), and higher education level of Higher Education). Based on the results of primary data processing on field observations, the frequency of education levels in the low category was 22 respondents $(34.38 \%)$, the medium category was 34 respondents $(53.12 \%)$, and the high category was eight respondents $(12.5 \%)$. So, the education level of the community in Sungai Durian Hamlet is in the high category, namely SMP / SMA. Table 3 shows that the most respondents of Inggit Strawberry agrotourism visitors are respondents whose last education is S1 and SMA/SMK as many as 27 and 13 people or with a percentage of $54 \%$ and $26 \%$. At the same time, the lowest is respondents whose education is Diploma, S2/ S3, elementary school, junior high school as many as $7,2,0,1$ people with a percentage of $14 \%, 4 \%, 0 \%, 2 \%$. This is because most of the respondents who visited Inggit Strawberry Agrotourism were people whose last education level was SMA/SMK and S1the level of education of tourists is in the very high category.

Based on Table 3 above, it can be seen that most of the respondents who visited the strawberry inggit agrotourism were private employees, students, entrepreneurs as many as $22,12,7$ people or $44,12.7 \%$, while the lowest respondents were TNI/Polri, businessmen, others, namely 0,3 , 3,3 with percentages of $0 \%, 6 \%, 6 \%, 6 \%$. This is because most of the respondents who come to visit Inggit Strawberry Agrotourism are mostly private employees. According to Pasdo (2018), respondents based on the type of work in this study were divided into three: farmers, private employees, and civil 
servants. Based on the results of primary data processing on field observations, 38 respondents $(59.38 \%)$, private employees $(28.13 \%)$, and civil servants (PNS) were eight respondents $(12.50 \%)$. The research results are more private staffing because the average employee can be seen from the age level, indicating that $17-25$ is very productive for tourism.

According to Saula (2019) For the city of origin, it is dominated by tourists who come from outside North Tapanuli by $60 \%$ and $40 \%$ from North Tapanuli. Based on Table 3. above, it can be seen that most of the respondents who travelled to Inggit Strawberry Agrotourism were the highest from the Magelang area, Yogyakarta, with an average of 23 people with a percentage of $46 \%$, while the minor regions were from the Banyubiru area, Bandungan, Grobogan, Central Kalimantan, Kendal, Pati, Purwodadi, South Sumatra, Solo with an average of 9 with a percentage of $18 \%$. This is because most of the respondents who visited Inggit Strawberry Agrotourism were from the Magelang area. Results of the study were more dominant in the place that visited the Inggit Strawberry agrotourism, namely the Magelang area $26 \%$ because this area was an area adjacent to the Inggit Strawberry agro-tourism. The study results were more dominant in the Inggit Strawberry agro-tourism area, namely the Magelang area $26 \%$ because this area was an area adjacent to the Inggit Strawberry agro-tourism.

According to Simanullang (2018), The respondent's visit rate was $>5$ times with 38 people or $38.0 \%$, followed by $4-5$ visits by 24 people or $24.0 \%$, then $2-3$ visits by 23 people or $23.0 \%$, and the first time visiting 15 people or $15.0 \%$. Based on Table 3. above, it can be seen that the number of visits to the strawberry inggit agrotourism during the last one month was the most for the first time, 2-3 visits, namely 37 and 9 people with a percentage of $74 \%$ and $18 \%$, while the lowest respondents were 3-4 times, $>5$ times. Namely 3 and 1, people with a percentage of $6 \%$ and $2 \%$ of all respondents. This is because most of the respondents were visiting Inggit Strawberry Agrotourism for the first time. The results obtained were as many as 37 people at the new visit at Inggit Strawberry. So it can be interpreted that half of Inggit Strawberry visitors are for the first time.

According to Simanullang (2018), Most of the reasons for visiting tourists are in the category of affordable ticket prices as many as 48 people or $48.0 \%$, followed by 32 or 32.0 tourists are in the variety of respondents' reasons for strategic location then 19 or $19.0 \%$ the reasons for visiting respondents are in the category of security and comfort atmosphere, and only one person or 1.0 tourists who visited Pondok Permai Beach on a school assignment. Based on Table 3 above, it can be seen that the number of visits to Inggit Strawberry Agrotourism, security, and comfortable atmosphere is the highest number of visits with a total of 21 people with a percentage of $46 \%$. At the same time, the lowest is school assignments/office assignments, with a total of zero / none. This is because safety and comfort are the most common reasons for respondents in Inggit Strawberry Agrotourism.

According to Saula (2019) research on visitor income/pocket money, research shows income is dominated by a range of less than 1 million, namely $34 \%$, followed by a range of 2 to 3 million 26 $\%$, and so on. Based on Table 3 above, it can be seen that most of the respondents who travelled in Inggit Strawberry agrotourism were a monthly income level of 2.5-5 million, as many as 20 people with a percentage of $40 \%$. In contrast, the lowest respondents were respondents with income $>5$ million, as many as six people with $12 \%$. Most of the respondents who visited the Inggit Strawberry agrotourism were private employees, so their income was 2.5 to 5 million. Results of the study show that $2.5-5$ million visitors have an average income which is high enough to make tourists in Inggit Strawberry.

\section{Analysis Customer Satisfaction Index}

According to Saula (2019), Satisfaction using the Customer Satisfaction Index obtained the satisfaction value over all of the attributes is $68.89 \%$ which is in the satisfied category. Even so, there are still attributes that are considered essential. Still, their performance is less than satisfactory, so improvements are needed so that the Satisfaction felt by tourists is following what is expected of the overall attributes.

Table 4, Analysis customer satisfaction index

\begin{tabular}{cclcc}
\hline Variables & \multicolumn{1}{c}{ Attributes } & Performance & Expectations \\
\hline Price & 1 & Price according to quality & 3.84 & 3.78 \\
& 2 & Price compared to competitors & 3.78 & 3.92 \\
& 3 & Price according to benefits & 4.14 & 4.14 \\
& 4 & Price list & 4.02 & 4.16 \\
\hline
\end{tabular}


Table 4, Analysis customer satisfaction index

\begin{tabular}{cclcc}
\hline Variables & & \multicolumn{1}{c}{ Attributes } & Performance & Expectations \\
\hline Product & 5 & The shape of fruit packaging & 4.12 & 4.06 \\
& 6 & Strawberry quality & 4.12 & 4.50 \\
& 7 & Strawberry size & 4.22 & 3.94 \\
& 8 & Product guarantee & 4.00 & 4.40 \\
\hline Advertisement & 9 & Banners & 4.14 & 4.22 \\
& 10 & Brochures & 3.92 & 4.32 \\
& 11 & Facebook & 4.04 & 4.20 \\
& 12 & Instragram & 3.96 & 4.34 \\
\hline Sales promotion & 13 & Special discounts & 4.16 & 4.18 \\
& 14 & Product sampling (strawberry) & 4.12 & 4.42 \\
& 15 & Free product packing (strawberry) & 4.18 & 4.42 \\
\hline Place & 16 & Strategic locations & 4.08 & 4.02 \\
& 17 & Arrangement of Place & 4.00 & 4.26 \\
\hline & \multicolumn{2}{c}{ Average Total } & 4,05 & 4,19 \\
\hline
\end{tabular}

Source: Primary Data Processed, 2021

According to Simanullang (2018), The attribute that has excellent performance according to respondents is attribute eight, which is about the ease of reaching the location of Pondok Permai Beach. This can be seen from the average performance, which gets the highest score, which is 4.18. Meanwhile, the lowest performance level attributes 11, which supports facilities and environments such as toilets, parking lots, and changing rooms in the Pondok Permai Beach tourist attraction with an average value of 3.66. The respondents are attributed 14, namely comfort and safety while on the beach, namely 4,28 . While for attributes with a low level of importance, namely the suitability of explaining all the information needed by tourists, it is obvious and detailed with an average significance level of 4.03. Respondents think this attribute is not very important because explaining all the information needed by tourists. It meets the standards of service that the Pondok Permai Beach tourism manager should provide.

Based on the results for the level of performance in Table 4. above, it turns out that the excellent performance attribute according to the respondent is the highest product attribute (strawberry size). This can be seen from the average performance, which has the highest score of 4.22. while the lowest statement is statement 3.78, namely the price attribute (price compared to competitors), respondents think it is less critical because the explanation and information are evident and detailed already meet the standards of the manager of Strawberry Inggit.

Based on the level of importance in Table 5. above, the most important attribute according to the respondents is the product attribute (strawberry quality) with an average value of 4.50 . In contrast, the lowest attribute is the price attribute (price according to quality), with an intermediate value level of importance of 3.78. Respondents thought that this attribute was less critical because the explanation and information provided were very clear and detailed and had met the standards of the strawberry inggit manager.

Table 5. Result importance performance analysis

\begin{tabular}{ccccc}
\hline No & MIS & WF & MSS & WS \\
\hline 1 & 3.78 & 5.30 & 3.84 & 20.36 \\
2 & 3.92 & 5.50 & 3.78 & 20.79 \\
3 & 4.14 & 5.81 & 4.14 & 24.05 \\
4 & 4.16 & 5.84 & 4.02 & 23.46 \\
5 & 4.06 & 5.70 & 4.12 & 23.47 \\
6 & 4.50 & 6.31 & 4.12 & 26.01 \\
7 & 3.94 & 5.53 & 4.22 & 23.33 \\
8 & 4.40 & 6.17 & 4.00 & 24.69 \\
9 & 4.22 & 5.92 & 4.14 & 24.51 \\
10 & 4.32 & 6.06 & 3.92 & 23.76 \\
11 & 4.20 & 5.89 & 4.04 & 23.80 \\
12 & 4.34 & 6.09 & 3.96 & 24.11 \\
13 & 4.18 & 5.86 & 4.16 & 24.40 \\
14 & 4.42 & 6.20 & 4.12 & 25.55 \\
15 & 4.42 & 6.20 & 4.18 & 25.92 \\
\hline
\end{tabular}


Table 5. Result importance performance analysis

\begin{tabular}{ccccc}
\hline No & MIS & WF & MSS & WS \\
\hline 16 & 4.02 & 5.64 & 4.08 & 23.01 \\
17 & 4.26 & 5.98 & 4.00 & 23.91 \\
\hline SUM & 71.28 & 100.00 & 68.84 & 405.11 \\
\hline MEAN & 4.193 & 5.882 & 4.049 & 23.83 \\
\hline \multicolumn{2}{c}{ Customer Satisfaction Index } & & 81,02 \\
\cline { 3 - 5 } & & &
\end{tabular}

Source: Primary Data Processed, 2021

In this study, the customer satisfaction (Customer Satisfaction Index) or, in this case, the customer in question is the community or tourists. Those who visited the Inggit Strawberry agrotourism, which was conducted with 50 respondents, were $81.02 \%$ which was rounded to $81 \%$ based on the results of the CSI. It can be seen that the interest in revisiting the Inggit Strawberry agro-tourism was in the very satisfied category. However, even though tourists are delighted with the performance that has been given, the strawberry inggit management officer. To see if there are statements that need to be improved in the future, and can use the importance-performance analysis (IPA) method. The research results above are the value of the calculation from the CSI, and the result is $81 \%$, where the value is very satisfying. It can be concluded that it is measured by 17 attributes and four variables with many respondents 50 81\% satisfied visitors have visited Inggit Strawberry

\section{Importance Performance Analysis}

According to Saula (2019), importance and performance on tourism bathing in North Tapanuli Using the Importance Performancemethod, it is Analysis (IPA) found that from 26 attributes, eight attributes are in quadrant A (main priority), namely A4, A6, A7, A12, A15, A16, A17, and A19. Then nine attributes in quadrant $B$ (maintain achievement), namely $A 1, A 2, A 3, A 5, A 13, A 14, A 20, A 24$, and $A 26$. There are six attributes in quadrant $C$ (low priority), namely $A 8, A 9, A 10, A 11, A 18$, and $A 21$, while in quadrant $D$ (excessive), there are three attributes A22, A23, and A25. Importance Performance Analysis (IPA) is used to find out how the manager of the Inggit Strawberry garden's performance has been given and what improvements need to be made by the Inggit Strawberry garden to increase customer satisfaction can be fulfilled. Importance describes how important the attributes of the marketing mix at that time were for consumers and performance. Describes the consumer's perception of the performance of the marketing mix attributes given by the manager of the strawberry inggit garden.

After all the questionnaire data is recapitulated, the next step is to calculate the number of each attribute per attribute and the average of each feature, both from expectation and performance. These values will describe the position of each component in the Cartesian diagram. The following is the calculation data for the results of the questionnaire:

Price is the amount of something that has value generally in the form of money that must be sacrificed to get a product. (Suparyanto \& Rosad, 2015) Based on calculates the average value of $Y$ (hope) that is 3,78 while the middle line $x$ (performance) with a weight of 4.00 in the presence of this calculation to calculate the line $y$ and $x$.

Table 6. Results of average calculation of the marketing mix (Price)

\begin{tabular}{clcccc}
\hline No & \multicolumn{1}{c}{ Attributes } & $\begin{array}{c}\text { Expectancy } \\
(\mathrm{Y})\end{array}$ & $\begin{array}{c}\text { Performance } \\
(\mathrm{X})\end{array}$ & $\begin{array}{c}\text { Average } \\
(\mathrm{Y})\end{array}$ & $\begin{array}{c}\text { Mean } \\
(\mathrm{X})\end{array}$ \\
\hline 1 & Price appropriate quality & 189 & 192 & 3.78 & 3.84 \\
2 & competitor's price & 196 & 189 & 3.92 & 3.78 \\
3 & Price accordance benefits & 207 & 207 & $4: 14$ & $4: 14$ \\
4 & List price & 208 & 201 & $4: 16$ & $4: 02$ \\
\hline & & & 16.00 & 15.78 \\
& & Total & 4.00 & 3.94 \\
\hline
\end{tabular}

Product is offered by producers for attention, interest, purchase, and consumption by the market to fulfil the needs and desires of the relevant market. (Tjiptono, 2012) Based on calculates the average value of $Y$ (hope) that is 4.06 while the middle line $x$ (performance) with a value of 4.2 in the presence of this calculation to calculate the line $y$ and $x$. 
Table 7. Results of average calculation of the marketing mix (product)

\begin{tabular}{clcccc}
\hline \multirow{2}{*}{ No } & \multicolumn{1}{c}{ Attributes } & $\begin{array}{c}\text { Expectancy } \\
(\mathrm{Y})\end{array}$ & $\begin{array}{c}\text { Performance } \\
(\mathrm{X})\end{array}$ & $\begin{array}{c}\text { Average } \\
(\mathrm{Y})\end{array}$ & $\begin{array}{c}\text { Mean } \\
(\mathrm{X})\end{array}$ \\
\hline 1 & packaging shape pieces & 203 & 206 & $4: 06$ & $4: 12$ \\
2 & Quality strawberry & 225 & 206 & $4: 50$ & $4: 12$ \\
3 & strawberry Size & 197 & 211 & 3.94 & $4: 22$ \\
4 & The product warranty & 220 & 200 & $4: 40$ & $4: 00$ \\
\hline & & & 16.90 & 16.46 \\
& & Total & & 4.22 & 4.11 \\
\hline
\end{tabular}

Advertising is any paid form of non-personal presentation and promotion of ideas, goods, or services by an identified sponsor with Sales promotion is the core ingredient in a marketing campaign, consisting of a collection of incentive tools, mostly short term, designed to stimulate the quicker or more excellent purchase of a particular product or service by consumers or trade(Shinta, 2017). used on calculates the average value of $Y$ (hope) that is 4.22 while the middle line $x$ (performance) with a value of 4.3 in the presence of this calculation to calculate the line $y$ and $x$.

Table 8. Results of average calculation of the marketing mix (advertising and sales promotion)

\begin{tabular}{|c|c|c|c|c|c|c|}
\hline No & Attributes & & $\begin{array}{c}\text { Expectancy } \\
(Y)\end{array}$ & $\begin{array}{l}\text { Performance } \\
(\mathrm{X})\end{array}$ & $\begin{array}{l}\text { Average } \\
(Y)\end{array}$ & $\begin{array}{l}\text { Mean } \\
(\mathrm{X})\end{array}$ \\
\hline 1 & Banner & & 211 & 207 & $4: 22$ & $4: 14$ \\
\hline 2 & Brochure & & 216 & 196 & $4: 32$ & 3.92 \\
\hline 3 & Facebook & & 210 & 202 & $4: 20$ & $4: 04$ \\
\hline 4 & Instragram & & 217 & 198 & 4:34 & 3.96 \\
\hline 5 & Pieces Special price & & 209 & 208 & $4: 18$ & $4: 16$ \\
\hline 6 & $\begin{array}{l}\text { The provision of } \\
\text { samples (strawberry) }\end{array}$ & product & 221 & 206 & $4: 42$ & $4: 12$ \\
\hline 7 & $\begin{array}{l}\text { Internet packing } \\
\text { (strawberry) }\end{array}$ & product & 221 & 209 & $4: 42$ & $4: 18$ \\
\hline \multicolumn{5}{|c|}{$\begin{array}{c}\text { Total } \\
\text { Average }\end{array}$} & $\begin{array}{c}30.10 \\
4.30 \\
\end{array}$ & $\begin{array}{c}28.52 \\
4.07 \\
\end{array}$ \\
\hline
\end{tabular}

One of the activities that every producer needs to do is move or distribute products, goods, or services produced from one place to another(Nurmi, 2015). Based on calculates the average value of $Y$ (hope) that is 4.02 while the middle line $x$ (performance) with a weight of 4.14 in the presence of this calculation to calculate the line $y$ and $x$.

Table 9. Results of average calculation of the marketing mix (Place)

\begin{tabular}{cccccc}
\hline \multirow{2}{*}{ No } & \multicolumn{1}{c}{ Attributes } & $\begin{array}{c}\text { Expectancy } \\
(\mathrm{Y})\end{array}$ & $\begin{array}{c}\text { Performance } \\
(\mathrm{X})\end{array}$ & $\begin{array}{c}\text { Average } \\
(\mathrm{Y})\end{array}$ & $\begin{array}{c}\text { Mean } \\
(\mathrm{X})\end{array}$ \\
\hline 1 & The strategic location & 201 & 204 & $4: 02$ & $4: 08$ \\
2 & Structuring place & 213 & 200 & $4: 26$ & $4: 00$ \\
\hline \multicolumn{7}{c}{} & & & 8.28 & 8.08 \\
& Total & & 4.14 & 4.04 \\
\hline
\end{tabular}

According to (Saula and Devis, 2019), calculation of the value of importance and performance on tourism bathing in North Tapanuli Using the Importance Performancemethod, is Analysis (IPA)found that from 26 attributes, eight attributes are in quadrant $A$ (main priority), namely $A 4, A 6$, $A 7, A 12, A 15, A 16, A 17$, and $A 19$. Then nine attributes in quadrant $B$ (maintain achievement), namely $\mathrm{A} 1, \mathrm{~A} 2, \mathrm{~A} 3, \mathrm{~A} 5, \mathrm{~A} 13, \mathrm{~A} 14, \mathrm{~A} 20, \mathrm{~A} 24$, and A26. There are six attributes in quadrant $\mathrm{C}$ (low priority), namely $A 8, A 9, A 10, A 11, A 18$ and $A 21$, while in quadrant $D$ (excessive), there are attributes, namely A22, A23, and A25. Based on the results of the calculation of the importance and performance of the three bathing tours in North Tapanuli using the IPA method, the attributes that intersect from the three research objects (have the position same in each quadrant in the diagram Cartesian), namely in the quadrants are A6, A7, A19, quadrant B A2, A3, A13, A24, and A26, in quadrant None and quadrant $D, A 23$. The slice results show that the attributes included in it are attributes that do have the same conditions on each object under study. The behaviour required for these attributes must be following their position in the results of the slice quadrant. Based on the above results of the average value of the attribute marketing mix can be seen of most of the existing attributes in quadrant I, namely as 
many as no characteristics quadrant II as many as 15 features quadrant III as many as two attributes, quadrant IV as many as no facts. for more details, can be seen in Figure 2. below.

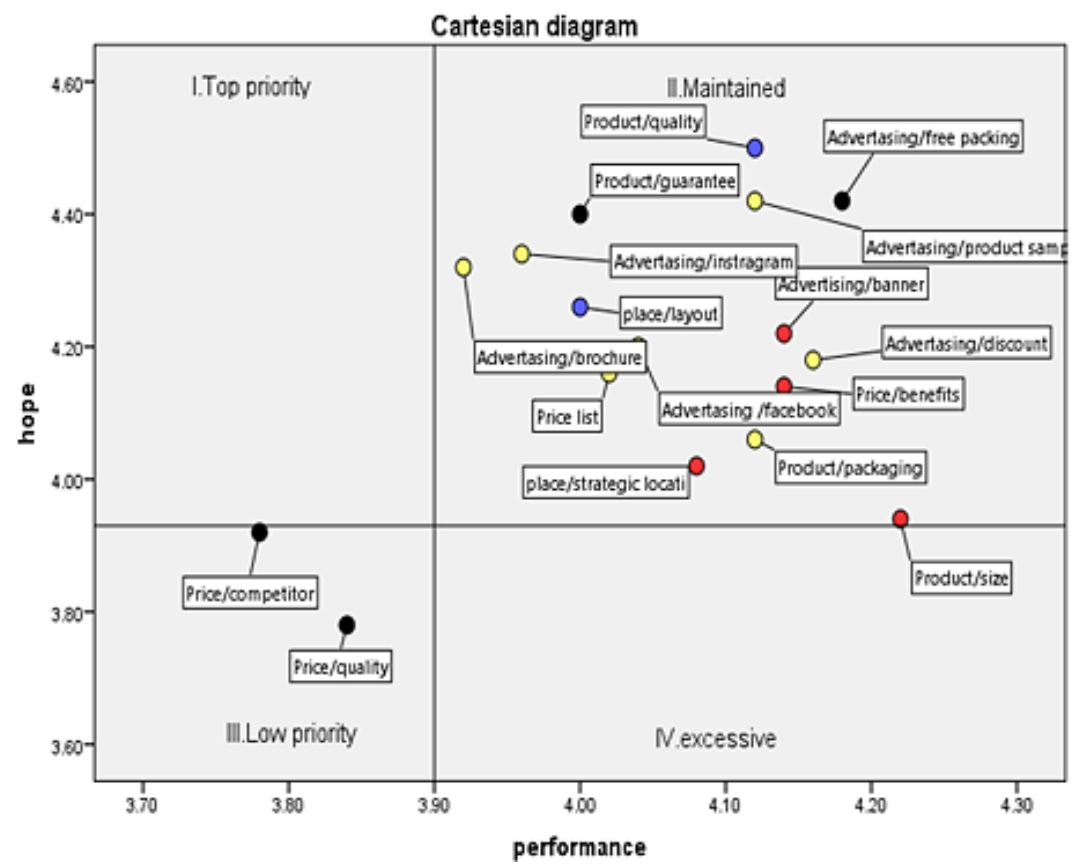

Figure 2. Processing method cartesian diagram IPA Results

Based on Figure 2. the lowest attribute is seen from the level of expectation, price/quality (price according to grade), with an average of 3, 78 in the priority quadrant. In contrast, the highest is based on the level of expectation, product/quality attributes (strawberry quality) with an average value of 4.12 in the achievement priority quadrant.

Based on Figure 2. the lowest attribute is seen from the level of performance, price/competitor (price compared to competitors), with an average value of 3.78 in the inferior priority quadrant. In contrast, the highest attribute is seen from the level of performance, product/size attributes (size strawberry), with an average value of 4.22 , which is included in the achievement priority quadrant.

\section{CONCLUSIONS AND SUGGESTION}

Based on the results of calculations using the customer satisfaction index (CSI) method, it can be seen that the CSI value is $81.02 \%$. This value belongs to the category of very satisfied it shows that customers are delighted with the services that have been provided by agrotourism inggit strawberry. But by looking at these results, there are still attributes that need to be improved so that future improvements can increase customer satisfaction. Even so, but there are attributes that are considered necessary, but its performance is less than satisfactory, so necessary improvements to perceived Satisfaction the rating according to dith what is expected in the overall attributes. Based on the calculations using the importance-performance analysis (IPA) method, the features that need improved performance to increase customer satisfaction are known. The results are based on the price/competitor attribute (price compared to competitors), with an average value of 3.78 used in this study. The calculation results with the lowest value are seen in Figure1. Cartesian diagram of the effects of processing the science method. Attributes of price/competitors (price compared to competitors) should managers review costs more with competitors around Inggit Strawberry so that prices and products match with competitors around Inggit Strawberry so that consumers are satisfied with the performance to match consumer expectations.

\section{REFERENCES}

Alma, B. (2016). Manajemen pemasaran dan pemasaran jasa (Alfabeta).

Assauri, S. (2013). Manajemen Pemasaran. In Dasar, Konsep dan Strategi.

Dany, f. . (2018). Analisis kepuasan pelanggan markobar dengan metode importance performance 
analysis (IPA) dan customer satisfaction index (CSI). Industrial Engineering.

Diana, panji, dita. (2014). Analisis persepsi konsumen menggunakan metode importance performance analysis dan customer satisfaction index. Jurnal Industrial, Vol 4 No 2, 74-81.

Evi, s. . (2018). Kepercayaan diri anak dalam pembelajaran pengembangan berbahasa pada kelompok b1 paud assalam muara bangkahulu kota bengkulu. Jurnal Ilmiah Pontesial, vol.3 (1).

Haris Fadillah, Aulia F. Hadining*, R. (2020). Analisis kepuasan pelanggan abc laundry dengan menggunakan metode service quality, importance performance analysis (IPA) dan customer satisfaction index (CSI). Jurnal Teknik Industri, 15, 1.

Hermawan, H. (2015). Analisis Pengaruh Bauran Pemasaran Terhadap Keputusan, Kepuasan, dan Loyalitas Konsumen dalam Pembelian Roti Ceria di Jember,. Jurnal Manajemen Dan Bisnis Indonesia, Vol. 1, No.

Hurriyati, R. (2015). Bauran Pemasaran dan Loyalitas Konsumen. Alfabeta.

Malau, H. (2017). Manajemen Pemasaran. Alfabeta.

Mawahib, M. J. (2015). Pengaruh Bauran PemasaranTerhadap Keputusan Pembelian. Jurnal Administrasi Bisnis (JAB), Vol 1, No.

Nurmi. (2015). Pengaruh bauran pemasaran (marketing mix) terhadap keputusan pembelian produk kacang telor ayam pada pt. Cahaya anugrah sentosa di kota makassar.

Pasdo, Emi, siti. (2018). Persepsi masyarakat terhadap air terjun rombo panga'a di desa antan rayan dusun sungai durian kabupaten landak sebagai destinasi wisata. Jurnal hutan lestari, Vol. 6 (4).

Popescu, G \& Vasile, A. J. (2015). Agricultural Management Strategies in a Charging Economy. IGI Global.

RISEP, N. (2018). Analisa kepuasan pelanggan dengan menggunakan metode customer satisfaction index (CSI) dan importance performance analysis (IPA). Seminar nasional sains dan teknologi terapan.

Santi, N. P. (2012). Hubungan Karakteristik Sosial DemoGrafi Konsumen Dengan Respon Terhadap Stimuli Komunikasi Pemasaran (Produk Bancassurance AAIA-BCA). Universitas Udayana.

Santoso. (2018). Menghitung tingkat kepuasan pelanggan.

Saula,devis, mariana. (2019). Analisis kepuasan wisatawan terhadap atribut wisata menggunakan metode csi dan ipa pada wisata pemandian di kabupaten tapanuli utara. Jurnal Sains Dan Teknologi, vol. 19 no.

Shinta, yola. (2017). pengaruh bauran promosi terhadap keputusan pembelian produk accu yuasa yang dipromosikan distributor pt riau indotama abadi di batam. Journal of Business Administration, vol.1 no.1.

Simanullang, R. . (2018a). Analisis tingkat kepuasaan wisatawan. Universitasitas sumatera utara.

Simanullang, R. . (2018b). Analisis tingkat kepuasan wisatawan di kabupaten serdang bedagai sumatera utara.

Sulaiman. (2015). Pengaruh Bauran Pemasaran Jasa Terhadap Kepercayaan Merek dan Dampaknya pada Keputusan Mahasiswa Memilih Kuliah di Politeknik Aceh,. Jurnal Manajemen, Vol. 4, No.

Suparyanto \& Rosad. (2015). Manajemen Pemasaran. In Media.

Suryawan, S dan Dharmayanti, D. (2013). Analisa Hubungan Antara Experential Marketing, Customer Satisfaction Dan Customer Loyalty Cafe Nona Manis Grand City Mall Surabaya. Jurnal Manajemen Pemasaran, vol.2 no.3.

Tjiptono, F. dan G. C. (2012). Pemasaran strategik (Andi (ed.)).

Umar, H. (2013). Riset pemasaran \& perilaku konsumen. PT Gramedia Pustaka Utama.

Vivi. (2017). Analisis kepuasan pelanggan terhadap pemanfaatan facebook commerce menggunakan metode importance performance analysis. Jurnal IImiah Matrix, vol.19.no1.

Yudi. (2017). Kualitas pelayanan bank dengan menggunakan metode importance performance analysis (IPA) dan customer satisfaction index (CSI) terhadap kepuasan nasabah. Jurnal IImiah Ekonomi Islam, Vol.03.No. 